\title{
Colonization by benthic macroinvertebrates in two artificial substrate types of a Riparian Forest
}

\author{
Colonização dos macroinvertebrados bentônicos em dois tipos de substratos artificiais \\ em uma Mata de Galeria
}

Lívia Borges dos Santos ${ }^{1 *}$, Cyntia Goulart Côrrea Bruno ${ }^{2}$ and Jean Carlos Santos ${ }^{3}$

${ }^{1}$ Programa de Pós-graduação em Ecologia e Conservação de Recursos Naturais, Universidade Federal de Uberlândia - UFU, Av. Pará, 1720, Uberlândia, MG, Brazil

${ }^{2}$ Programa de Pós-graduação em Biologia Comparada, Universidade de São Paulo - USP, Av. Bandeirantes, 3900, Ribeirão Preto, SP, Brazil

${ }^{3}$ Laboratório de Ecologia-Evolução e Biodiversidade - LEEBIO, Instituto de Biologia - InBio, Universidade Federal de Uberlândia - UFU, Av. Pará, 1720, Uberlândia, MG, Brazil *e-mail: lilabs.07@hotmail.com

Cite as: Santos, L.B., Bruno, C.G.C. and Santos, J.C. Colonization by benthic macroinvertebrates in two artificial substrate types of a Riparian Forest. Acta Limnologica Brasiliensia, 2016, vol. 28, e24.

\begin{abstract}
Aim: To analyze the efficiency of organic and inorganic substrates in samples of benthic macroinvertebrates of riparian forests from the Cerrado. Specific objectives: (i) characterize the ecological succession and taxonomic richness of benthic macroinvertebrates in stream affluent of a riparian forest; (ii) analyze the influence of seasonality on the colonization of macroinvertebrates; and (iii) determine the effect of the types of artificial substrates on the richness, composition and abundance of the benthic community. Methods: Sampling was carried out in the rainy and dry seasons, and we installed in the watercourse two types of substrates: organic (leaf packs) and inorganic (bricks), organized in pairs. Six samples per season were done to verify colonization, succession, richness and abundance of benthic community. The substrates were carefully sorted and the organisms were identified to the lowest possible taxonomic level. Results: The ecological succession was clearly observed, with the initial occurrence of Chironomidae and Baetidae (considered early colonizers), and a late occurrence of organisms such as Helotrephidae and Trichoptera (considered late colonizers). No significant difference was found in the richness and abundance among the studied seasons (rainy and dry), but the organic substrate was significantly higher than the inorganic substrate for these parameters. Conclusion: Organic artificial substrates are more efficient in characterizing the community of benthic macroinvertebrates in the study area, because they are more similar to the conditions of the substrate found naturally in the environment.
\end{abstract}

Keywords: ecological succession; organic substrates; leaf pack; brick; Cerrado.

Resumo: Objetivo: Analisar a eficiência de substratos orgânicos e inorgânicos para a amostragem de macroinvertebrados bentônicos em matas ripárias de Cerrado. Objetivos específicos: (i) Caracterizar a sucessão ecológica e riqueza taxonômica dos macroinvertebrados bentônicos em um afluente de um ribeirão de mata de galeria; (ii) analisar a influência da sazonalidade sobre a colonização de macroinvertebrados; e (iii) verificar o efeito dos tipos de substratos artificiais sobre a riqueza e a abundância da comunidade bentônica. Métodos: As amostragens foram realizadas nas estaçóes chuvosa e seca do ano de 2014, e foram instalados no curso d'água dois tipos de substratos: os orgânicos (leaf packs) e os inorgânicos (lajota), organizados por pares. No total foram realizadas seis coletas por estação, que ocorreram em dias determinados, para se verificar a colonização, sucessão, riqueza e 
abundância da comunidade bentônica. Os substratos foram cuidadosamente triados e os organismos foram identificados até o menor nível taxonômico possível. Resultados: A sucessão ecológica foi claramente observada, com a ocorrência inicial de organismos das famílias Chironomidae e Baetidae, colonizadores iniciais, e uma ocorrência tardia de outros organismos como Helotrephidae e Trichoptera, colonizadores tardios. Não houve diferença significativa na riqueza e abundância entre as estaçôes estudadas (chuva e seca), porém o substrato orgânico apresentou valores significativamente maiores que o substrato inorgânico para estes parâmetros. Conclusão: Os substratos artificiais orgânicos são mais eficientes na caracterização da comunidade dos macroinvertebrados bentônicos na área de estudo, por se assemelharem mais às condiçóes do substrato naturalmente encontrado no ambiente.

Palavras-chave: sucessão ecológica; substratos orgânicos; leaf pack; lajota; Cerrado.

\section{Introduction}

Benthic macroinvertebrates (BM) have a huge ecological importance to many aquatic ecosystems, e.g., they have a key role in food chains (Suriano \& Fonseca-Gessner, 2013). These organisms are an important link between the basal resources and fish (Callisto et al., 2001). Moreover, they can degrade allochthonous material of aquatic ecosystems (Carvalho \& Uieda, 2004). Due to its great diversity and occurrence in multiple habitats, $\mathrm{BM}$ are commonly used in ecological assessment of aquatic ecosystems (Milesi et al., 2008).

The BM fauna present in an ecosystem can be measured and characterized by colonization of patterned substrates (Esteves et al., 2011). This important tool also makes it possible to analyze changes in richness and composition of communities over time (ecological succession), and determine the exact time from this process (Ribeiro \& Uieda, 2005). Several studies of BM colonization use artificial substrates to characterize the benthic fauna (e.g., Leite-Rossi et al., 2015; Pereira et al., 2010; Wantzen \& Pinto-Silva, 2006).

Artificial substrates are elements used to transcribing environmental characteristics to be studied (Bicudo \& Bicudo, 2004). These substrates can be divided into organic and inorganic group. Inorganic substrates, such as rocks, do not decompose because they are not chemically active. Conversely, this occurs in organic substrates, such as leaves and trunks of riparian trees.

The use of artificial substrates has advantages and disadvantages. Some advantages correspond as having the smallest sample variability, the fact of not damaging the environment and having less foreign material in the sample unit (which occurs in nets sampling) (Resh \& Jackson, 1993). Besides, it is easy to purchase because of their low cost. Some disadvantages are the possibility of occurring habitat selection by specialist organisms (Leite-Rossi et al., 2015), not having information about the local substrate and the need of a relatively long time for colonization to reach the equilibrium community (Esteves et al., 2011).

Given the importance of using artificial substrates in the study of benthic macroinvertebrates, evaluating the efficiency of them for sampling the benthic community is of great importance, especially in ecosystems where these studies have not been conducted. This study had the following objectives: (i) characterize the ecological succession and taxonomic richness of benthic macroinvertebrates in stream affluent of a riparian forest; (ii) analyze the influence of seasonality on the colonization of macroinvertebrates; and (iii) determine the effect of the types of artificial substrates [organic (leaf pack) and inorganic (brick)] on the richness, composition and abundance of the benthic community. Based on these objectives, the following hypotheses were tested: (1) colonization and succession: this hypothesis predicts an increase in richness and abundance, as well as a substitution of species (or taxa) over time in both substrates (Thomazi et al., 2008); (2) Seasonal variation: this hypothesis predicts greater richness and abundance of macroinvertebrates in the dry season (Esteves et al., 2011) and (3) type substrate: this hypothesis predicts greater richness and abundance in the organic type substrate due to greater availability of resources and similarity for the natural substrate (Bruno et al., 2012; Thomazi et al., 2008).

\section{Material and Methods}

\subsection{Study area}

This study was conducted in a first order stream, affluent of 'Ribeirão do Panga', situated in a privately conservation area, the Panga Reserve of Universidade Federal de Uberlândia, in Uberlândia, Minas Gerais, Brazil (Figure 1). The stream has intact and stable margins, of a riparian forest of Cerrado, without signs of erosion and/or sedimentation of the channel or any anthropic impact (Cardoso et al., 2009; Bruno et al., 2012). The climate is marked by two distinct seasons: the 


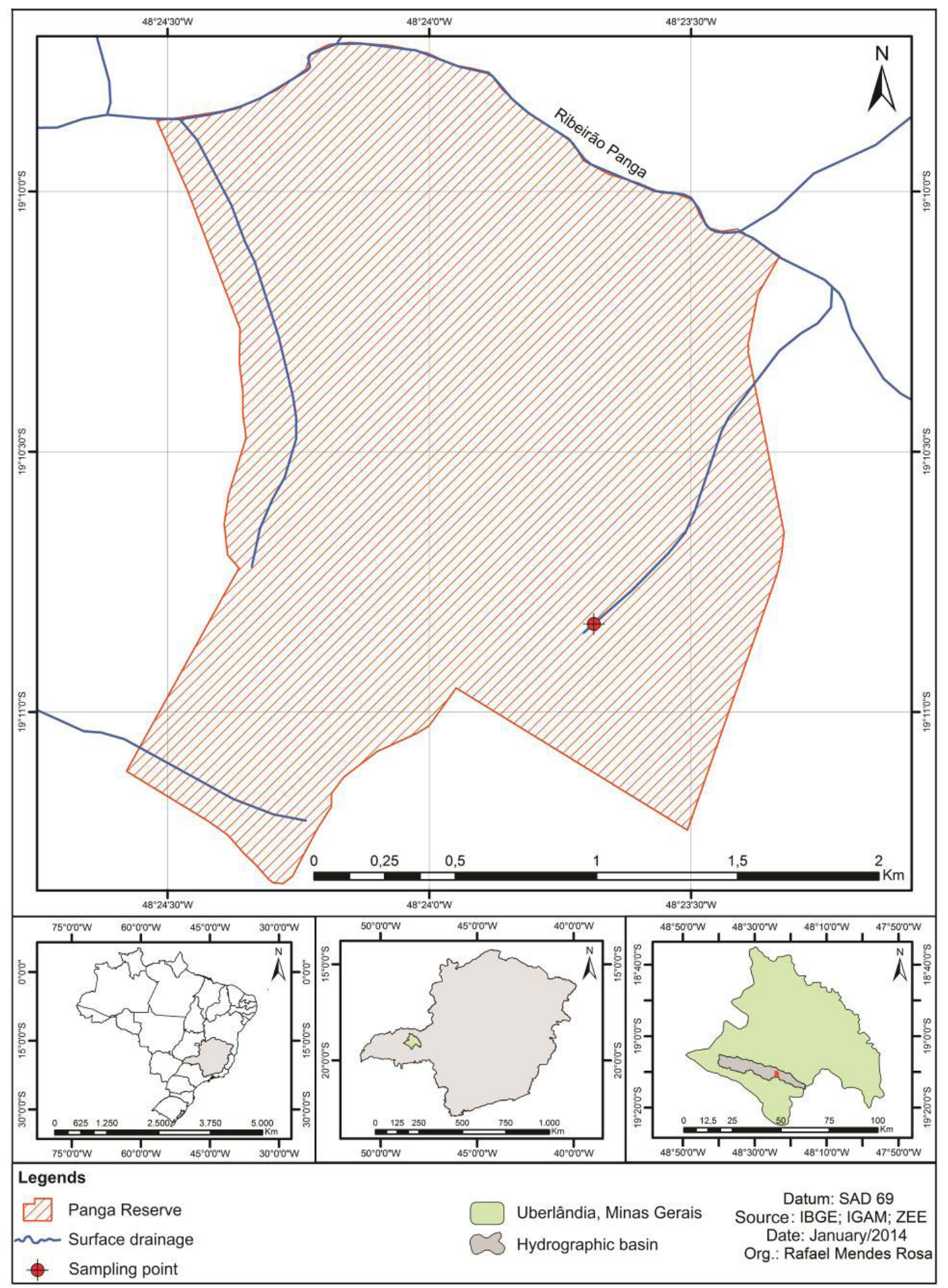

Figure 1. Location of sampling point in affluent of 'Ribeirão do Panga', Uberlândia, Minas Gerais, Brazil.

dry, with drought from May to September with an average temperature of $19.3^{\circ} \mathrm{C}$ and average rainfall of $26.36 \mathrm{~mm}$, and wet from October to April with an average temperature of $23.9^{\circ} \mathrm{C}$ and average rainfall of $318.9 \mathrm{~mm}$, representing $86.7 \%$ of the total annual rainfall (Silva \& Assunção, 2004).

\subsection{Experimental design}

The experiment was conducted during the rainy (February/2014) and dry season (May-June/2014). It was prepared two types of artificial substrates, with similar dimensions (Figure 2): Organic substrate - leaf pack (size $200 \times 150 \mathrm{~mm}$ and $25 \mathrm{~mm}$ 


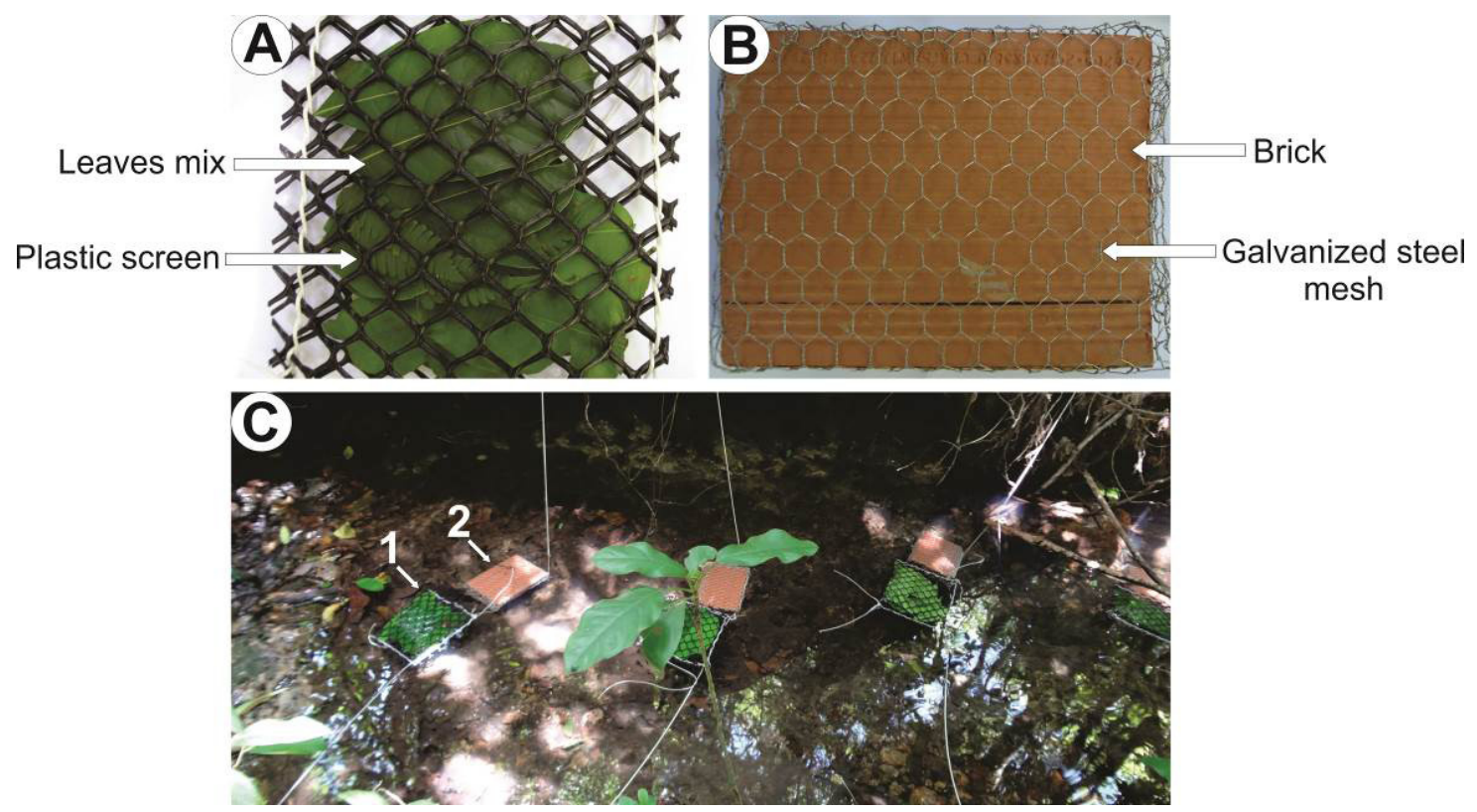

Figure 2. Artificial substrates used in the sampling of benthic macroinvertebrates. (A) Leaf pack, organic substrate; (B) Brick, inorganic substrate; (C) Each pair with each type of substrate (1) leaf pack and (2) brick.

mesh plastic screen with a mixture of fresh random leaves containing four plant species from the studied riparian stream) and inorganic substrate - brick (size $195 \mathrm{~mm}$ long by $155 \mathrm{~mm}$ wide by $45 \mathrm{~mm}$ deep with galvanized steel $12.5 \mathrm{~mm}$ mesh). The substrates were arranged in six pairs (each pair with each type of substrate) and distributed along the stream with an average distance of $0.5 \mathrm{~m}$ per pair.

For the samplings in the rainy season, the pairs of substrates were installed on the first day of February and in the dry season, on the thirty-first day of May. Thus, the samples were taken, respectively, in 3th (S1 = Sampling 1), 5th (S2 = Sampling 2), 7th (S3 = Sampling 3), 14th (S4 = Sampling 4), 21th (S5 = Sampling 5) and 28th (S6 = Sampling 6) days after installation, and on each gathering it was removed a pair of substrates with network "D" support ( $0.25 \mathrm{~mm}$ mesh). The materials were individualized in plastic containers, specifying the type of substrate and date of sampling, with fixation in 3\% formalin.

The samples were processed by triage of all the material and the organisms were identified and quantified with stereomicroscope using a specialized identification keys (see Bruno et al., 2012; Esteves et al., 2011; Merrit \& Cummins, 1996). The family category was the lowest taxonomic level used to determine the OTU (Operational Taxonomic Units) (Carvalho \& Uieda, 2004). It was not possible to identify some classes and orders like Hirudinea, Oligochaeta and Lepidoptera, due to the difficulty of visualization in key features. In this study, the richness was analyzed using the number of OTU's as unit.

\subsection{Statistical analyses}

Quantitative data are presented as mean \pm SE. Normality was tested using Shapiro-Wilk test and homoscedasticity using Levene's test. Where appropriate, data were transformed using $\log _{10}$ (Zar, 1999). The differences between the samplings, seasons and substrates in relation to richness and abundance were evaluated using repeated measure ANOVA test (performed by a General Linear Model/GLM) and multiple comparisons were carried out using Tukey's test for pairwise comparisons. Statistical procedures were performed using Minitab 17.1.0 software. The abundance was determined by quantitative count of each OTUs found in each substrates (for sampling day). Due to the low sample size data, sampling of each substrate were added to obtain variance and used in the GLM model to test the influence of seasonality and time (colonization) on the richness and abundance of macroinvertebrates.

\section{Results}

Overall, the succession in the rainy season was marked by an initial colonization of Chironomidae and Baetidae, which remained throughout the sampling period. Baetidae presented an increasing abundance to S4 (14th day), and kept stable until the 21 th day, before rising again in the last sampling 
(28th day). The other groups were only recorded from S2 (5th day), but their presence have not been stabilized and had a low abundance (Figure 3A). In the dry season, the main family of colonizers was Baetidae, which also remained present throughout the whole sample, with varying abundance. However, despite the Chironomidae appeared only in S2 (5th day), their abundance increased to S5 (21th day), predominating over other organisms, which had lower abundance values (Figure 3B).

Initial colonization of Chironomidae in brick (Figure 4A) and Baetide in leaf pack (Figure 4B) marked the succession patterns found in substrates.
Late organisms of brick were Helotrephidae, Philopotamidae and Calamoceratidae, while for the leaf pack were Ceratopogonidae, Elmidae and Hydropsychidae. The most striking difference between the substrates was the occurrence of Baetidae in brick (dry season), which occurred only in S6 (typical of late organism) (Figure 4A); while for leaf pack, they were colonizers in the two seasons, appearing in all samples (Figure 4B). Finally, the leaf pack supported a greater diversity of organisms during the colonization, probably due to its availability of food resources. The OTU's number to leaf pack varies between 9 and 15 in the dry and
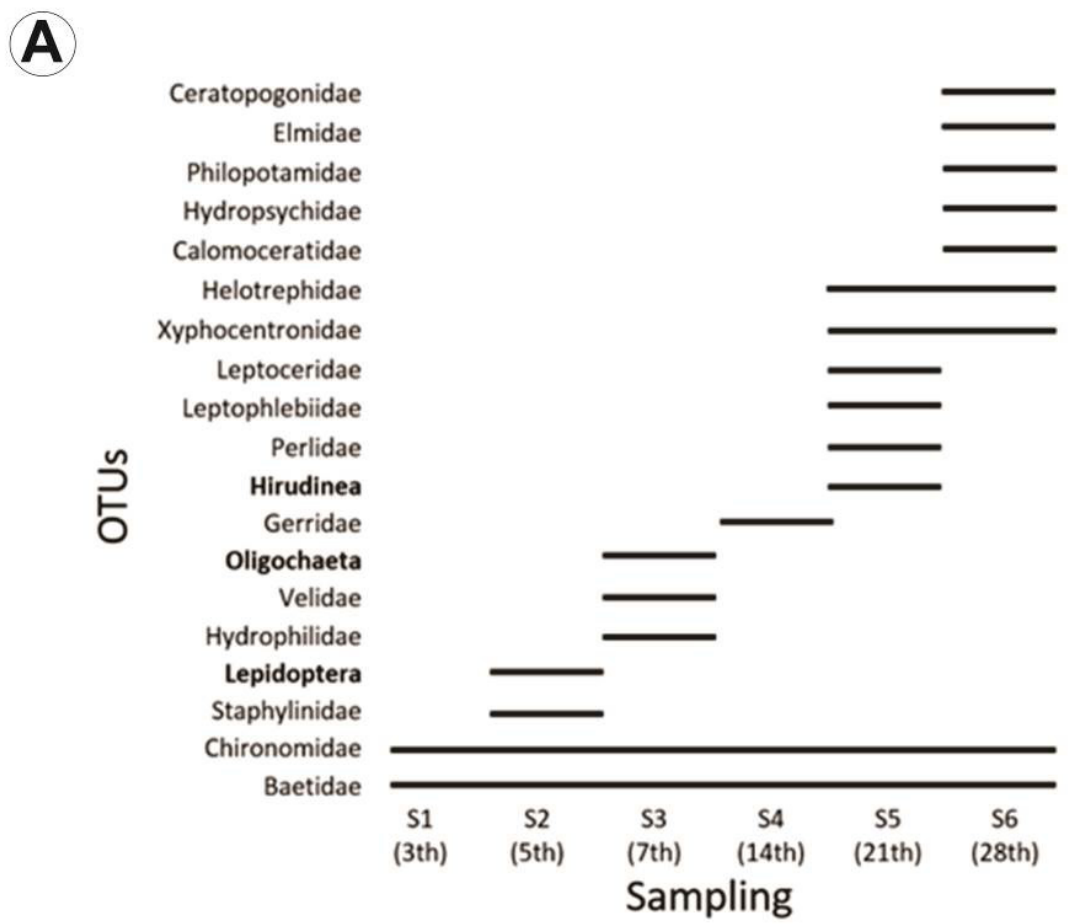

B

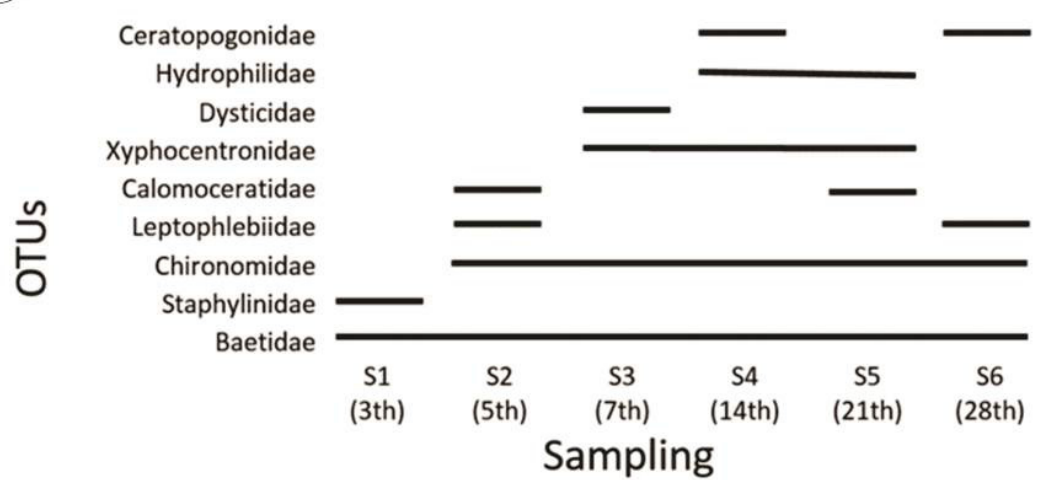

Figure 3. Succession and colonization of benthic macroinvertebrates adding the two types of substrates (brick and leaf pack) by season [rainy (A) and dry (B)] in affluent of 'Ribeirão do Panga', Uberlândia, Minas Gerais, Brazil. Legend: The lines in OTUs indicate their presence in marked sampling (S). 
Brick - Rainy

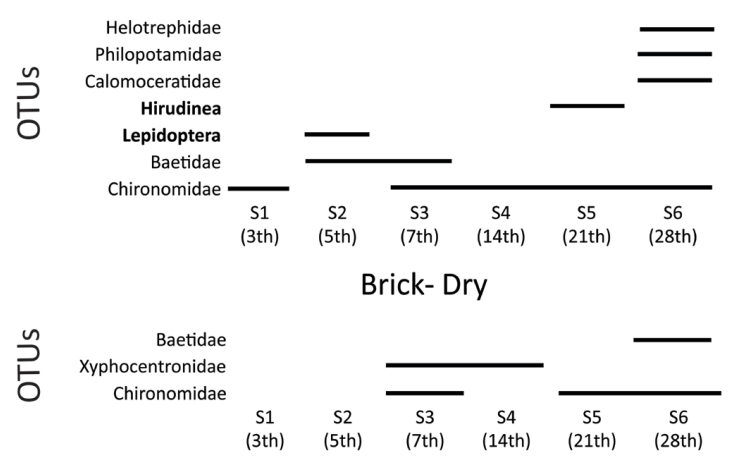

Sampling

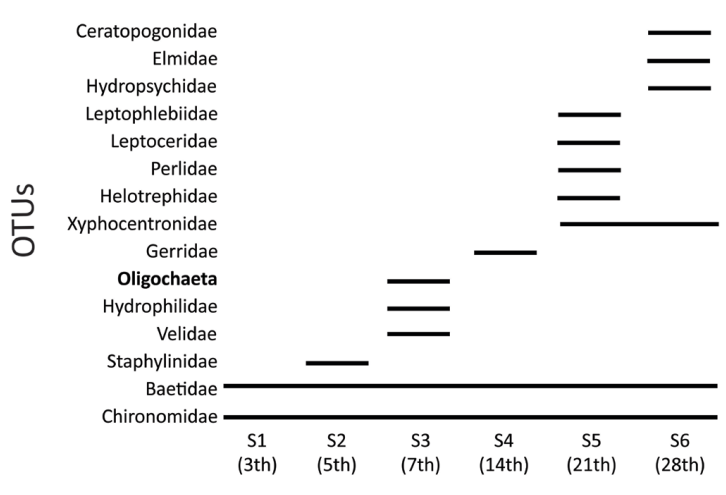

Leaf Pack - Dry

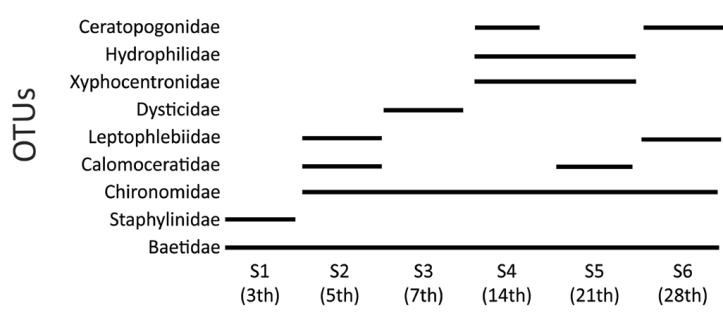

Sampling

Figure 4. Succession and colonization of benthic macroinvertebrates for each substrate [brick (A) and leaf pack (B)] by season (rainy and dry) in affluent of 'Ribeirão do Panga', Uberlândia, Minas Gerais, Brazil. Legend: The lines in OTU's indicate their presence in marked sampling $(\mathrm{S})$.

rainy season respectively, and to brick between 3 and 7 in the dry and rainy season, respectively.

The results of the ANOVA test showed that abundance did not vary significantly between sampling seasons ( $p>0.05$, Table 1, Figure 5A). Thus, the dry and rainy periods did not affect the amount of organisms that colonize new available substrates. However, the variation was significantly different between the samples (time) and the type of substrate. The Tukey's test analysis indicated that the abundance values collected in S1, S2, S3 and S4 were not significantly different from one another, despite the progressive increase among them. The variation in abundance was significantly higher only in the final samples (S5 and S6) $(p<0.05$, Table 1, Figure 5B). Regarding the substrates, the abundance of individuals in leaf packs was significantly higher than that found in bricks $(p<0.05$, Table 1, Figure 5C) and each substrate tends to be more abundant over time (Figure 6).

The results showed that richness did not vary significantly between seasons $(p>0.05$, Table 2, Figure 7A). Regarding the collection time, the richness of macroinvertebrates showed no significant differences between some samplings, despite the increase presented in the Figure 7B.
Table 1. Result of General Linear Model (GLM) (repeated measure ANOVA test) for abundance of benthic macroinvertebrates between season, sampling and substrate in an affluent of 'Ribeirão do Panga', Uberlândia, Minas Gerais, Brazil.

\begin{tabular}{lcrrrr}
\hline & DF & \multicolumn{1}{c}{ SS } & \multicolumn{1}{c}{ MS } & F-value & p-value \\
\hline Season & 1 & 0.2763 & 0.2763 & 1.25 & 0.281 \\
Sampling & $\mathbf{5}$ & $\mathbf{1 3 . 5 0 0 7}$ & $\mathbf{2 . 7 0 0 1}$ & $\mathbf{1 2 . 1 7}$ & $\mathbf{0 . 0 0 0}$ \\
Substrate & $\mathbf{1}$ & $\mathbf{2 3 . 3 3 5 1}$ & $\mathbf{2 3 . 3 3 5 1}$ & $\mathbf{1 0 5 . 1 9}$ & $\mathbf{0 . 0 0 0}$ \\
Error & 16 & 3.5493 & 0.2218 & & \\
(within) & & & & & \\
Total & 23 & 40.6614 & & & \\
\hline
\end{tabular}

DF = Degrees of freedom; SS = Sum of squares; $\mathrm{MS}=$ Mean sum of squares.

However, S3 and S5 collects were significantly different from S1 (Tukey's test) ( $p<0.05$, Table 2, Figure 7B). Richness also varied significantly between the substrates. The leaf pack showed greater richness of macroinvertebrates than brick substrate $(p<0.05$, Table 2, Figure 7C). The richness of organisms has increased over time to both substrates (Figure 8), indicating colonization, as was the appearance of organisms beyond the colonizers, such as representatives from Leptophlebiidae and Hydrophilidae, which appeared only in the 14th day. 
A

B
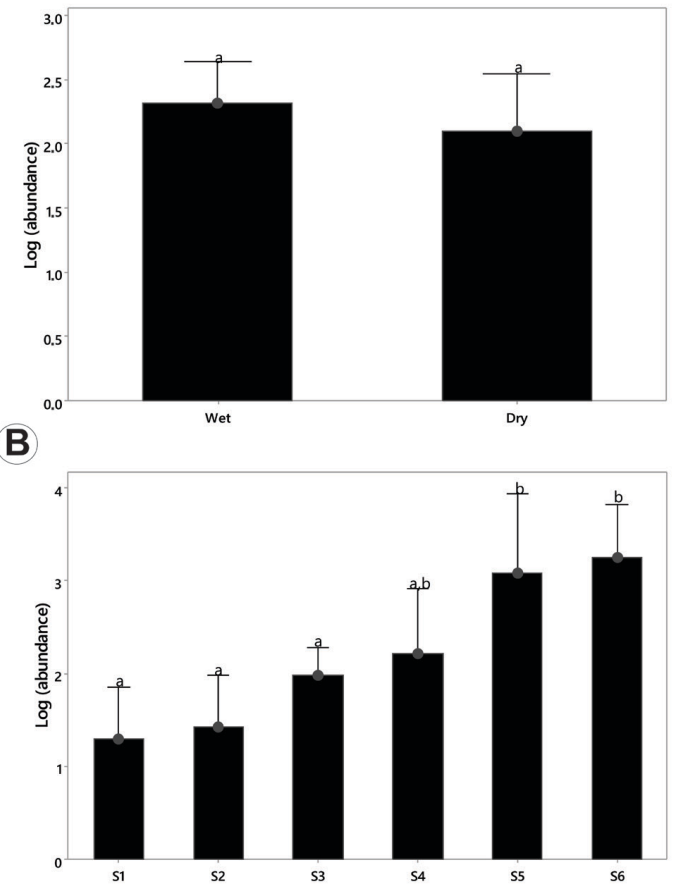

C

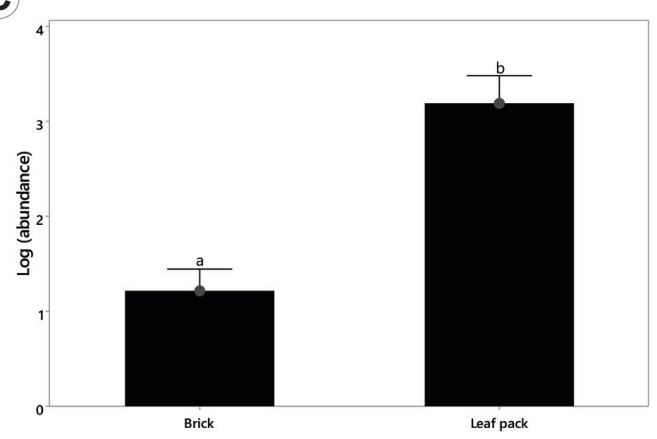

Figure 5. Changes in abundance of benthic macroinvertebrates among season (wet and dry) (A), sampling (successional time) (B) and substrate (brick and leaf pack) (C). Means with the same letter are not statistically different according to Tukey's test.

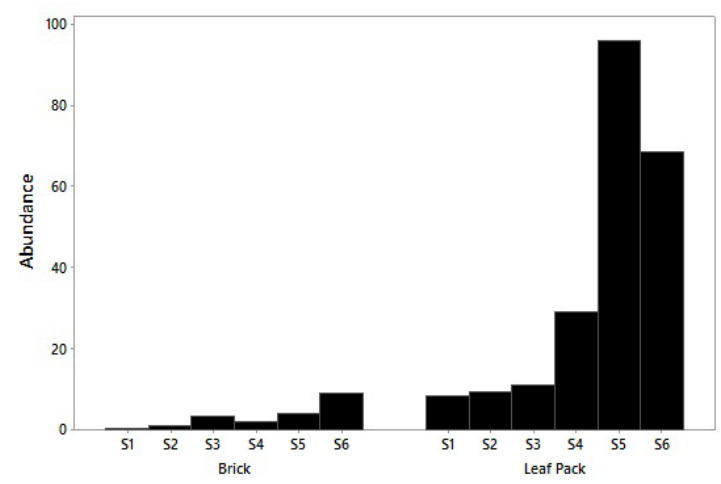

Figure 6. Changes in abundance of benthic macroinvertebrates among sampling (successional time) for each substrate (brick and leaf pack).
A

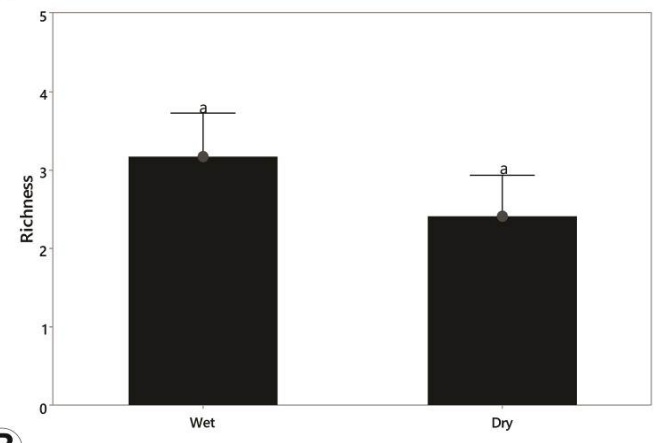

B

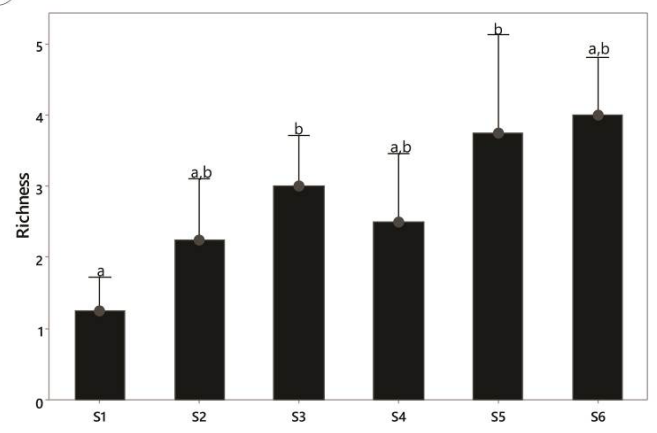

(C)

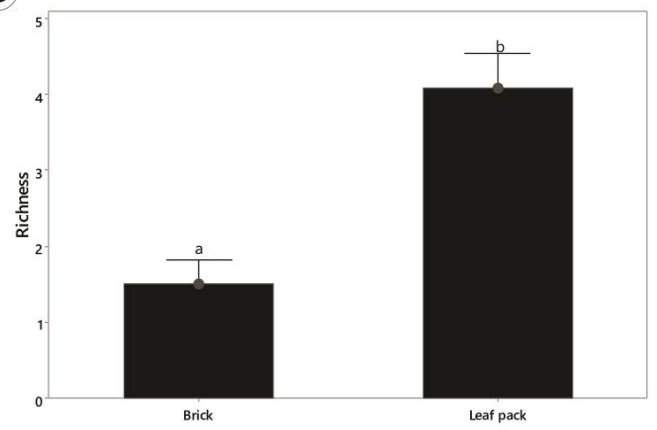

Figure 7. Changes in richness of benthic macroinvertebrates among season (wet and dry) (A), sampling (sucessional time) (B) and substrate (brick and leaf pack) (C). Means with the same letter are not statistically different according to Tukey's test.

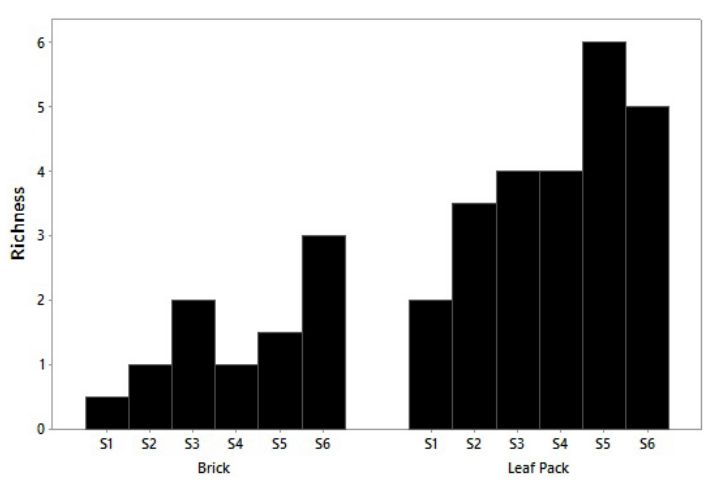

Figure 8. Changes in richness of benthic macroinvertebrates among sampling (successional time) for each substrate (brick and leaf pack). 
Table 2. Result of General Linear Model (GLM) (repeated measure ANOVA test) for richness of benthic macroinvertebrates between season, sampling and substrate in an affluent of 'Ribeirão do Panga', Uberlândia, Minas Gerais, Brazil.

\begin{tabular}{llrrrr}
\hline & DF & \multicolumn{1}{c}{ SS } & \multicolumn{1}{c}{ MS } & F-value & $\boldsymbol{p}$-value \\
\hline Season & 1 & 3.375 & 3.3750 & 3.41 & 0.083 \\
Sampling & $\mathbf{5}$ & $\mathbf{2 0 . 7 0 8}$ & $\mathbf{4 . 1 4 1 7}$ & $\mathbf{4 . 1 9}$ & $\mathbf{0 . 0 1 3}$ \\
Substrate & $\mathbf{1}$ & $\mathbf{4 0 . 0 4 2}$ & $\mathbf{4 0 . 0 4 1 7}$ & $\mathbf{4 0 . 4 6}$ & $\mathbf{0 . 0 0 0}$ \\
$\begin{array}{l}\text { Error } \\
\text { (within) }\end{array}$ & 16 & 15.833 & 0.9896 & & \\
Total & 23 & 79.958 & & & \\
\hline
\end{tabular}

$\mathrm{DF}=$ Degrees of freedom; SS = Sum of squares; MS $=$ Mean sum of squares.

\section{Discussion}

The richness and composition of organisms sampled in "Ribeirão do Panga" affluent were in accord with expectations due to the good quality of this watercourse in the study area. Moreover, the affluent also offered a good qualified environment and habitat heterogeneity for benthic macroinvertebrates. The results were representative for all the EPTs, as well as other common organisms such as the Chironomidae. Individuals from Ephemeroptera, Plecoptera and Trichoptera are known to be susceptible organisms and have they occurrence restricted to environments with low human impact (Buss et al., 2004; Bispo et al., 2006). Silveira et al. (2006), in their study on biological assessment of water quality in two watersheds of the river Mogi Guaçu, São Paulo, has also recorded the Chironomidae as the most frequent, because they are common organisms. They also found Chironomidae in all sampling points of river Mogi Guaçu, including anthropogenic passages, but families such as Vellidae and Perlidae were registered only on not impacted points (Silveira et al., 2006). There's a few searchs about the studied stream, but the results in relation to the benthic community structure patterns was according to the commonly observed in the stream evaluated, thus the substrate used (especially the leaf pack) was effective in sample the benthic community of the study area (Guimarães-Souto et al., 2014; Bruno et al., 2012).

Overall, the abundance increased significantly in the final samples (S5 and S6), indicating a growing number of organisms on the both substrates analyzed, as expected by our hypothesis. Dipteran individuals (e.g., Chironomidae) remained present in all samples, increasing up to the 21 th day, as well as Ephemeroptera, which also increased its density along the samplings. These results corroborated similar findings observed by Carvalho \& Uieda (2004) in an experiment of colonization in natural and artificial substrates in Ribeirão da Quinta in Itatinga, São Paulo, where Diptera was quite representative and Ephemeroptera was late colonizer. In the final sampling, the presence of a larger amount of OTU's caused a significant increase in richness. This suggests a possible ecological succession because, according to Brower (1984), in the successional process, colonization of less fastidious organisms leads to changes in the environment. Consequently, it will offer favorable conditions for more demanding specialized organisms and can be a late colonizer.

In the rainy season, the succession began with initial colonization from Chrironomidae and Baetidae and a late colonization from Helotrephidae and Trichoptera (Philopotamidae, Calomoceratidae and Xyphocentronidae), with a reduction in the abundance of Chironomidae in the last collection. Thomazi et al. (2008) obtained similar results, with the late onset of Trichoptera and Chironomidae decrease, as chironomids (pioneers) have disadvantages within the competition for food and space, due to the great mobility of Trichoptera (late) (Thomazi et al., 2008). However, in the dry season, the succession showed different results, because Chironomidae was present only in S2, with higher frequencies in the following samplings.

We expected that the rainy season had presented lower values of richness and abundance of benthic macroinvertebrates, as was observed in similar studies (Thomazi et al., 2008; Ribeiro \& Uieda, 2005). According to Thomazi et al. (2008), because of the current increased by the rainfall, there will be a drag formation in the river below organisms, reducing abundance and richness of benthic macroinvertebrates. However, this study did not confirm this hypothesis, since neither the abundance nor the richness differed between sampling stations. This may be related to the year collection (2014), which was atypical due to lack of rainfall in the study area.

The substrates showed significant differences in the richness and abundance of BM, and were significantly higher in leaf pack substrate. This result is in accordance with the expectations, as the organic substrate is attractively more similar to the natural habitat and provides many resources (Bicudo \& Bicudo, 2004). On the other hand, the bricks offer refuge to BM against running water and risk predation. The leaf pack has heterogeneous adhesion substrates, according Sanseverino \& Nessimian 
(2008), provide the aquatic community source of food and/or shelter against the running water and predators, which can positively influence the richness and the distribution of aquatic organisms. However, most of the analyzed studies (Carvalho \& Uieda, 2004; Thomazi et al., 2008) always make use of inorganic substrates for sampling, and the organic substrates are rarely mentioned.

Thus, the study showed that the organic substrates are better samplers when compared to inorganic substrates, and therefore should be more researched and used, for a better sampling of the organisms, preventing the discrepancy between the natural and artificial substrate interfere in the sample. Besides, it showed colonization and succession also, in which there was an increase of richness and abundance, as well as a substitution of species (or taxa) over time in both substrates.

\section{Acknowledgements}

The authors thank Mr. Celso dos Santos for fieldwork. We also thank the Post-Graduate Program of Ecology and Conservation of Natural Resources - Federal University of Uberlândia for financial funds. We would like to thank staff of the Reserva Ecologica do Panga of Universidade Federal de Uberlândia for logistical support. This study had financial support from Capes (Coordination for the Improvement of Higher Education Personnel), CNPq (National Counsel of Technological and Scientific Development) and Fapemig (Foundation of Support Research of the State of Minas Gerais).

\section{References}

BICUDO, C.E.M. and BICUDO, D.C. Amostragem em Limnologia. 2nd ed. São Carlos: Rima, 2004.

BISPO, P.C., OLIVEIRA, L.G., BINI, L.M. and SOUSA, K.G. Ephemeroptera, Plecoptera and Trichoptera assemblages from riffles in mountain streams of Central Brazil: environmental factors influencing the distribution and abundance of immatures. Brazilian Journal of Biology $=$ Revista Brasileira de Biologia, 2006, 66(2B), 611-622. PMid:16906293.

BROWER, J.H. The natural occurrence of the egg parasite, Trichogramma, on almond moth eggs in peanut storages in Georgia. Journal of the Georgia Entomology Society, 1984, 19, 285-290.

BRUNO, C.G.C., BATISTA, J.E., SOUZA, J.R., PAULA, S.M., BRITO, B.A., JACOBUCCI, G.B. and CAMELO, F.R.B. Comparação entre a eficiência de amostragem de dois tipos de substratos artificiais instalados em córregos do cerrado. Revista Brasileira de Zoociências, 2012, 14(1), 123-134.
BUSS, D.F., BAPTISTA, D.F., NESSIMIAN, J.L. and EGLER, M. Substrate specificity, environmental degradation and disturbance structuring macroinvertebrate assemblages in Neotropical streams. Hydrobiologia, 2004, 518, 179-188.

CALlisto, M., MORENO, P. and BARBOSA, F.A.R. Habitat diversity and benthic functional trophic goups at Serra do Cipó, Southeast Brazil. Revista Brasileira de Biologia, 2001, 61(2), 259-266. PMid:11514893.

CARDOSO, E., MORENO, M.I.C., BRUNA, E.M. and VASCONCELOS, H.L. Mudanças fitofisionômicas no cerrado: 18 anos de sucessão ecológica na estação ecológica do Panga, Uberlândia MG. Caminhos de Geografia, 2009, 10(32), 254-268.

CARVALHO, E.M. and UIEDA, V.S. Colonização por macroinvertebrados bentônicos em substrato artificial e natural em um riacho da serra de Itatinga, São Paulo, Brasil. Revista Brasileira de Zoologia, 2004, 21(2), 287-293. http://dx.doi.org/10.1590/S010181752004000200021 .

ESTEVES, F.A., LEAL, J.J.F. and CALLISTO, M. Comunidade Bentônica. In: F.A. ESTEVES, ed. Fundamentos de limnologia. 3rd ed. Rio de Janeiro: Interciência, 2011, pp. 581-607.

GUIMARÁES-SOUTO, R.M., CORBI, J.J. and JACOBUCCI, G.B. Diagnóstico Ambiental de Organoclorados em Sedimentos e Invertebrados Bentônicos de Bacias Hidrográficas do Triangulo Mineiro, Minas Gerais, Brasil. Revista Brasileira de Recursos Hidricos, 2014, 19(1), 143-153. http:// dx.doi.org/10.21168/rbrh.v19n1.p143-153.

LEITE-ROSSI, L.A., RODRIGUES, G.N. and TRIVINHO-STRIXINO, S. Aquatic macroinvertebrate colonization of artificial substrates in low-order streams. Biotemas, 2015, 28(3), 69-77.

MERRIT, R. and CUMMINS, K. An introduction to the aquatic insects of North America. Kendall: Hunt Publishing, 1996.

MILESI, S.V., BIASI, C., RESTELLO, R.M. and HEPP, L.U. Efeito de metais cobre $(\mathrm{Cu})$ e Zinco $(\mathrm{Zn})$ sobre a comunidade de macroinvertebrados bentônicos em riachos do sul do Brasil. Acta Scientiarum: Biological Sciences, 2008, 30(3), 283-289.

PEREIRA, D., MANSUR, M.C.D., VOLKMERRIBEIRO, C., OLIVEIRA, M.D., SANTOS, C.P. and BERGONCI, P.E.A. Colonização de substrato artificial por macroinvertebrados límnicos, no delta do rio Jacuí (RS, Brasil). Biotemas, 2010, 23(1), 101-110.

RESH, V.H. and JACKSON, J.K. Rapid assessment approaches to biomonitoring using benthic macroinvertebrates. In: D.M. ROSENBERG and V.H. RESH. Freshwater biomonitoring and benthic macroinvertebrates. New York: Chapman \& Hall, 1993, pp. 195-233. 
RIBEIRO, L.O. and UIEDA, V.S. Estrutura da comunidade de macroinvertebrados bentônicos de um riacho de serra em Itatinga, São Paulo. Revista Brasileira de Zoologia, 2005, 22(3), 613-618.

SANSEVERINO, A.M. and NESSIMIAN, J.L. Larvas de Chironomidae (Diptera) em depósito de folhiço em um riacho de primeira ordem da Mata Atlântica (Rio de Janeiro, Brasil). Revista Brasileira de Entomologia, 2008, 52(1), 95-104.

SILVA, E.M. and ASSUNÇÃO, W.L. O clima na cidade de Uberlândia - MG. Sociedade \& Natureza, 2004, 3(16), 91-107.

SILVEIRA, M.P., QUEIROZ, J.F., FERRAZ, J.M.G., RIBACINKO, D.B., CARVALHO, M.P., MARIGO, A.L., SITTON, M., ZAMBON, G. and SILVA, J.R. Avaliação biológica da qualidade da água em duas microbacias do Rio Mogi Guaçu (SP) e sua relação com os impactos agrícolas. O Biológico, 2006, 68, 737-743. Supplement.

SURIANO, M.T. and FONSECA-GESSNER, A.A. Structure of benthic macroinvertebrate assemblages on a gradient of environmental integrity in Neotropical streams. Acta Limnologica Brasiliensia, 2013, 25(4), 418-428.

THOMAZI, R.D., KIIFER, W.P., FERREIRA JUNIOR, P.D. and SÁ, F.S. A sucessão ecológica sazonal de macroinvertebrados bentônicos em diferentes tipos de atratores artificiais no rio Bubu, Cariacica, ES. Natureza Online, 2008, 6(1), 1-8.

WANTZEN, K.M. and PINTO-SILVA, V. Uso de substratos artificiais para avaliação do impacto do assoreamento sobre macroinvertebrados bentônicos em um córrego de Cabeceira no Pantanal do Mato Grosso, Brasil. Revista Brasileira de Recursos Hidricos, 2006, 11(1), 99-107.

ZAR, J.H. Biostatistical analysis. London: Prentice Hall, 1999.

Received: 18 May 2016 Accepted: 16 November 2016 